PiOTR DAWIDKO

Uniwersytet Jagielloński

\title{
Biotechnologiczne spółki spin-off Uniwersytetu Jagiellońskiego jako mechanizm transferu technologii
}

Innowacyjne sektory wysokich technologii są uważane za jeden z najważniejszych elementów nowoczesnej gospodarki. Branża biotechnologiczna doskonale spełnia kryteria przynależności do sektorów tego rodzaju, zaś przez niektórych badaczy (Cooke 2004) jej rozwój uznawany jest wręcz za nieodzowny dla funkcjonowania współczesnej gospodarki. W zaawansowanych technologicznie gałęziach przemysłu postęp jest niemożliwy bez dostępu do wiedzy i innowacji, których najważniejszym źródłem są instytucje badawczo-rozwojowe zarówno będące częściami firm, jak i państwowe jednostki badawcze i edukacyjne (placówki szkolnictwa wyższego).

W przypadku sektora biotechnologicznego, w odróżnieniu od pozostałych branż innowacyjnych, większość innowacji powstaje na terenie dedykowanych jednostek badawczych - głównie uniwersytetów (Eliasson 2000). Stąd też podstawą rozwoju tego sektora jest sprawny proces rozprzestrzeniania wiedzy, umożliwiający szybkie przenikanie najnowszych innowacji do gospodarki. Landry (2006) wyróżnia w tym przypadku trzy główne drogi dyfuzji: targi i konferencje, proces edukacyjny wykwalifikowanych pracowników oraz komercjalizację wiedzy. Komercjalizacja dokonuje się natomiast poprzez: usługi doradcze, badania kontraktowe, patentowanie (oraz późniejszą sprzedaż patentów) a także powstawanie firm typu spin-off. W branży biotechnologicznej największe znaczenie ma ostatnia z wymienionych form (Landry 2006).

Akademickie firmy spin-off, będące najważniejszym elementem rozwoju sektora biotechnologicznego, w Polsce znajdują się w inicjalnym stadium rozwoju. Działalność tego typu pozostawała niezauważana przez władze i organizacje wsparcia przedsiębiorczości niemalże do połowy pierwszej dekady XXI wieku. Dopiero napływ funduszy Unii Europejskiej nakierowanych na rozwój innowacyjnych przedsiębiorstw oraz swoista „moda na innowacyjność" spowodowały wzrost zainteresowania spin-offami (pierwsza publikacja dotycząca firm spin-off w sektorach wysokich technologii, finansowana przez PARP, została wydana w 2006 r.). 
Uniwersytet Jagielloński jest jedną z dwóch (obok Uniwersytetu Rolniczego) krakowskich uczelni prowadzących kształcenie na kierunku biotechnologia i jedyną, której obecni bądź byli pracownicy naukowi prowadzą działalność gospodarczą typu spin-off. Firmy te stanowią ważny, ze względu na swoją innowacyjność, element krakowskiego skupienia biotechnologiczno-farmaceutycznego (Klastra Life Science).

\section{DZIAŁALNOŚĆ SPIN-OFF}

Firma typu spin-off jest definiowana jako ,[...] osobny podmiot prawny, powstały na bazie technologii dostarczonej przez instytucję-matkę i wsparty finansowo np. przez fundusz venture capital" (Tamowicz 2006, s. 11). Ujęcie to uwzględnia zarówno spin-offy akademickie, jak i tworzone przez pracowników innych firm. W specyficznym przypadku działalności prowadzonych przez pracowników naukowych uczelni (spin-offów akademickich) przydatna jest również definicja pochodząca z dokumentów Uniwersytetu Jagiellońskiego, według której spin-off jest to „,...] spółka, powołana w celu rozwijania i komercjalizacji dóbr intelektualnych należących do Uniwersytetu" (Regulamin: zasady tworzenia spótek spin-off w Uniwersytecie Jagiellońskim).

Kwestią sporną w literaturze pozostaje zagadnienie stopnia skodyfikowania transferowanej technologii. W podejściu klasycznym spin-offem jest działalność oparta na konkretnej technologii (patencie), będącym własnością zespołu założycielskiego fïmy. Według ujęć bardziej liberalnych (m.in. Birley 2002, Nicolaou 2003) dopuszczalny jest również nieskodyfikowany i nietechniczny charakter wiedzy, będącej przedmiotem transferu. Wiedza ta określana jest jako aktywa intelektualne założycieli, a do spółek spin-off zaliczane są również np. wyspecjalizowane firmy doradcze prowadzone przez akademików.

Najważniejszą cechą przestrzenną działalności typu spin-off, podkreślaną przez wielu autorów (m.in. Abramovsky 2011, Decarolis 1999, Ter Wal 2007, Lawton-Smith 2006, Sorenson 2003), jest ich tendencja do lokalizacji w pobliżu instytucji-matki. Istnieją dwa wyjaśnienia tego trendu. Pierwsze z nich odwołuje się do „twardych” czynników lokalizacji - obecność instytucji-matki, najczęściej będącej dużej wielkości podmiotem gospodarczym lub naukowym, przyczynia się do wytworzenia korzyści aglomeracji, wykorzystywanych przez nowopowstające przedsiębiorstwa (Decarolis 1999). Dostosowany rynek pracy, obecność wyspecjalizowanych instytucji otoczenia biznesu czy potencjalnych partnerów stwarza dogodne warunki dla znajdujących się w inicjalnej fazie rozwoju firm spin-off. Drugie wyjaśnienie omawianego zjawiska podkreśla z kolei rolę czynników „miękkich”, a zwłaszcza uczestnictwa zakładających działalność spin-off przedsiębiorców w lokalnych sieciach społecznych, co związane jest z ich poprzednią pracą w instytucji-matce. Sorenson (2003) uznaje lokalne sieci społeczne za najważniejszy kanał przepływów wiedzy, a także wyróżnia dwa ich rodzaje: związane z przepływami wiedzy specjalistycznej oraz oparte o wymianę informacji na temat miejscowego środowiska biznesowego. Wiedza specjalistyczna, a zwłaszcza wiedza ukryta (tacit knowledge), odnosząca się do osobistych, praktycznych doświadczeń z pracy w danej branży, przepływa głównie kanałami nieformalnymi, w czasie osobistych spotkań pracowników określonego sektora. Stąd też wynika silne zakorzenienie lokalne jej przepływów (Coenen 2004). Przepływy drugiego rodzaju wiedzy przebiegają podobnymi 
kanałami - głównie poprzez nieformalne spotkania, grupy i więzi społeczne. Dlatego też rozpoczynający działalność przedsiębiorcy mają najlepszą informację na temat niezagospodarowanych nisz rynkowych oraz zasobów koniecznych do prowadzenia zyskownej działalności, jeśli ich nowa firma działa w branży, w której pracowali wcześniej i jest zlokalizowana w miejscu o znanym im środowisku biznesowym.

Opisane założenia zostały zweryfikowane empirycznie w badaniu amerykańskiego sektora biotechnologicznego (Sorenson 2003). Zgodnie z jego wynikami, głównym źródłem nowopowstających działalności są istniejące firmy i instytucje, zaś najważniejszym czynnikiem warunkującym przetrwanie na rynku jest dostęp do specjalistycznej i biznesowej wiedzy. Jedynie kilku przedsiębiorców nie wywodzących się z sektora biotechnologicznego uczestniczyło w lokalnych sieciach społecznych na tyle głęboko, by posiąść wiedzę na temat możliwości prowadzenia udanej działalności oraz zmobilizować odpowiednie zasoby kapitału intelektualnego, ludzkiego i finansowego.

Z zagadnieniem dostępu do wiedzy ściśle wiąże się przeżywalność firm na rynku. W przypadku działalności typu spin-off można mówić o potencjalnie wysokiej przeżywalności, co potwierdzają badania empiryczne (m.in. Lawton-Smith 2006, 2008). W brytyjskim przemyśle samochodowym, według badań przeprowadzonych przez Boschmę i Wentiga (2004), spółki spin-off charakteryzowały się najwyższą przeżywalnością, większą nawet od ich instytucji-matek, co ma związek z większą innowacyjnością i elastycznością spin-offów.

„Lokalny” charakter powstawania i działalności firm typu spin-off wskazuje na ich ważną rolę w powstawaniu i ewolucji skupień (klastrów) przedsiębiorstw. Skupienia uznawane są za kluczowe ośrodki danej branży, charakteryzujące się największą produktywnością i innowacyjnością (Porter 1990). Według Ter Wala i Boschmy (2007) za podstawowe czynniki wzrostu i ewolucji skupień można uznać procesy naśladownictwa (imitowanie udanych działalności) wśród przedsiębiorców oraz dynamikę powstawania spin-offów. Powstawanie spin-offów stanowi również jeden z czterech mechanizmów lokalnych przepływów wiedzy wśród przedsiębiorstw zlokalizowanych w danym skupieniu, obok nieformalnych kontaktów, sieci kooperacyjnych i procesów rozlewania się wiedzy związanych z mobilnością kadr (Ter Wal 2007).

\section{WSPÓŁCZESNY SEKTOR BIOTECHNOLOGICZNY}

Ze względu na swoją interdyscyplinarność i związki z innymi branżami, sektor biotechnologiczny jest pojęciem trudnym do jednoznacznego zdefiniowania. Niektórzy badacze wręcz odżegnują się od definiowania biotechnologii jako sektora, traktując ją jako pewien zestaw działań, podejmowanych przez przedsiębiorców działających w różnych branżach (Lawton-Smith 2008). Według najpowszechniej uznawanego podziału, działalności biotechnologiczne dzieli się na trzy specjalizacje:

- biotechnologię medyczną (,czerwoną”),

- biotechnologię rolniczą (,zieloną”),

- biotechnologię przemysłową („,białą”).

Każda z wymienionych powyżej specjalizacji posiada swoje charakterystyczne cechy odnoszące się do wielkości, modeli biznesowych i preferencji lokalizacyjnych przedsię- 
biorstw, a także kształtu i roli sieci wiedzy. Łączy je natomiast wysoka innowacyjność, często określana jako warunek przetrwania danego przedsiębiorstwa na rynku (Mroczkowski 2006).

W przypadku biotechnologii medycznej cechą decydującą o kształcie sektora są trudności wielkich korporacji farmaceutycznych w prowadzeniu prac badawczo-rozwojowych w tej dziedzinie. Jest to thumaczone przede wszystkim niezwykle szybkim tempem innowacji oraz szerokim spektrum zastosowań biotechnologii, wymagającym tworzenia wielu zespołów naukowych, wąsko wyspecjalizowanych w jednej dziedzinie i posiadających dostęp do specjalistycznej wiedzy ukrytej, tworzonej najczęściej na uniwersytetach i w innych placówkach badawczo-rozwojowych (Coenen 2004). Ze względu na niezwykle wysokie potencjalne koszty utrzymywania zespołów badawczych i ograniczone możliwości zmiany dziedziny ich pracy, korporacje farmaceutyczne decydują się na outsourcing prac B+R bądź kupno licencji lub patentu w wyspecjalizowanych w danej dziedzinie firmach biotechnologicznych. Spółki te, najczęściej będące spin-offami tworzonymi przez uniwersyteckie zespoły naukowe, skupiają się najczęściej na jednej dziedzinie badań, doprowadzając innowacje stworzone przez założycieli w ramach pracy naukowej do postaci możliwej do zastosowania w praktyce (Lawton-Smith 2008).

Duża rola uniwersytetów oraz wspomnianych wyżej innowacyjnych spółek biotechnologicznych doprowadziła do wykształcenia się charakterystycznego modelu komercjalizacji innowacji w biotechnologii medycznej. Występuje w nim trzech głównych graczy: uniwersytety (lub inne jednostki badawczo-rozwojowe) jako źródło innowacji, dedykowane firmy biotechnologiczne jako wykonawcy prac $\mathrm{B}+\mathrm{R}$ oraz korporacje farmaceutyczne jako nabywcy innowacji, odpowiedzialni za ostateczne sprawdzenie jej przydatności rynkowej (testy kliniczne), upscaling przemysłowy oraz późniejszą sprzedaż i marketing (ryc. 1).

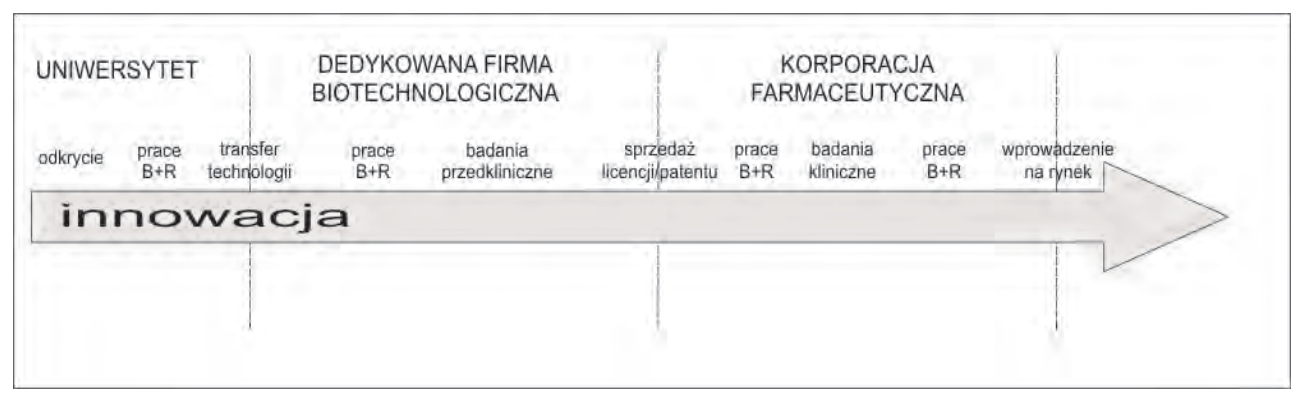

Ryc. 1. Model komercjalizacji innowacji w biotechnologii medycznej

Źródło: opracowanie własne na podstawie Mroczkowski 2006

Działalność spółek biotechnologicznych opiera się w dużej mierze na zewnętrznych źródłach finansowania; najważniejszym z nich są umowy licencyjne z korporacjami farmaceutycznymi. Umowy tego typu zakładają zwykle wypłaty kolejnych transz finansowania po osiągnięciu specyficznych kamieni milowych w pracach $\mathrm{B}+\mathrm{R}-\mathrm{w}$ przypadku opóźnień firma skazana jest na poszukiwanie alternatywnych metod finansowania działalności (Andersson 2010). Cykl prac B+R w biotechnologii medycznej, od momentu rozpoczęcia działalności do sprzedaży patentu lub licencji na wytwarzanie, trwa zwykle ok. 6-7 lat (Lawton-Smith 
2008). W tym czasie koszty utrzymania zespołu naukowego, specjalistycznego laboratorium, zakupu materiałów, sprzętu itd. obciążają w całości budżet firmy. Biorąc pod uwagę fakt otrzymywania wynagrodzenia jedynie w przypadku (niepewnych) pozytywnych rezultatów badań w określonym czasie, firmy często zmuszane są do poszukiwania alternatywnych źródeł finansowania działalności $\mathrm{B}+\mathrm{R}$ - np. poprzez sprzedaż specjalistycznych usług (badania usługowe, doradztwo), pośrednictwo w sprzedaży wyposażenia laboratoryjnego i odczynników itd. Inną drogą zabezpieczenia finansowania jest debiut giełdowy, zwłaszcza na alternatywnych rynkach obrotu (np. NewConnect GPW w Warszawie, AIM giełdy londyńskiej czy NASDAQ). Nie zmienia to faktu niezwykłej wrażliwości modelu biznesowego firm biotechnologicznych oraz dużego ryzyka związanego z prowadzeniem tego typu działalności - porównywanej często do gry w ruletkę (Andersson 2010, Mroczkowski 2006).

Czynnikiem, który pomimo dużego ryzyka przyciąga przedsiębiorców do tego typu działalności jest perspektywa wielkich zysków oraz przykłady historii sukcesu, wyzwalające procesy naśladownictwa. W warunkach polskich takim przykładem jest kontrakt krakowskiej grupy Selvita z fińską korporacją Orion Pharma, dotyczący innowacyjnego leczenia choroby Alzheimera (SEL103). Wartość pierwszego, podpisanego w 2010 r. kontraktu na sprzedaż licencji przez polską spółkę biotechnologiczną szacowana jest na ok. $300 \mathrm{mln}$ zł.

Jak wskazano wcześniej, większość dedykowanych firm biotechnologicznych występujących w największych skupieniach branży wywodzi się od akademickich spółek spin-off (Lawton-Smith 2008). Firmy te zachowują najważniejszą cechę charakterystyczną spin-offów w zakresie przestrzennym, tzn. lokalizację w pobliżu swojej instytucji-matki. Wpływają na to zarówno czynniki „twarde” (korzyści aglomeracji), jak i „miękkie” (sieci społeczne).

W przypadku tych pierwszych, dostęp do rozwiniętych i wyposażonych laboratoriów - zapewnianych w inicjalnej fazie rozwoju sektora głównie przez instytucję-matkę - jest uważany za jeden z kluczowych elementów stymulujących powstawanie nowych działalności (Landry 2006).

Kolejnym elementem wpływającym na lokalizację spółek biotechnologicznych jest uczestnictwo założycieli w sieciach społecznych, a zwłaszcza kontakty z innymi profesjonalistami z danej dziedziny, umożliwiające przepływy specjalistycznej wiedzy ukrytej. Transmisja wiedzy ukrytej, nieskodyfikowanej i przekazywanej głównie kanałami nieformalnymi jest silnie uzależniona od odległości i rzadko wykracza poza zasięg przestrzenny lokalnego skupienia. Ponieważ innowacyjność w branży biotechnologicznej opiera się w dużej mierze o przepływy i akumulację wiedzy ukrytej, wpływ bliskiej lokalizacji firm i jednostek naukowych ma niebagatelne znaczenie dla ich funkcjonowania (Coenen 2004).

Powyższe cechy lokalizacji przedsiębiorstw kształtują obraz biotechnologii medycznej jako branży silnie skoncentrowanej przestrzennie, której głównymi elementami są skupienia firm i instytucji otoczenia biznesu wokół przodujących jednostek naukowo-badawczych (Cooke 2004). Silne związki z lokalnym środowiskiem wskazują też na endogeniczny charakter rozwoju sektora. Biotechnologiczne firmy typu spin-off nie tylko utrzymują silne więzi ze swoimi instytucjami-matkami, ale również preferują zlokalizowane w pobliżu przedsiębiorstwa jako swoich dostawców, kooperantów i partnerów (Lawton-Smith 2006).

Najważniejszymi czynnikami, wpływającymi na rozmaite trajektorie rozwoju skupień branży biotechnologicznej, są m.in. poziom badań naukowych w regionie, obecność instytucji otoczenia biznesu i gęstość instytucjonalna (institutional thickness), a także czynniki społeczne i kulturowe, charakteryzujące środowisko naukowców i przedsiębiorców. 
Za najważniejsze instytucje otoczenia innowacyjnego biznesu uważa się centra transferu technologii, parki naukowo-technologiczne, inkubatory przedsiębiorczości oraz inicjatywy klastrowe. Stworzenie sprawnego systemu wsparcia komercjalizacji technologii, umożliwiającego chętnym naukowcom prowadzenie działalności gospodarczej w sprzyjających warunkach, znacznie zwiększa liczbę tworzonych firm spin-off (Lawton-Smith 2006). Równie duże znaczenie ma obecność odpowiednich mechanizmów finansowania działalności przedsiębiorstw specjalizujących się w pracach $\mathrm{B}+\mathrm{R}$, a zwłaszcza funduszy kapitału zalążkowego (seed i venture capital). Za cenę utraty części udziałów w spółce, poszukujący finansowania przedsiębiorcy mają możliwość otrzymania znacznego wsparcia kapitałowego oraz dostępu do doświadczonej kadry zarządzającej. Jednakże korzystanie z usług tego typu funduszy często budzi opór naukowców-przedsiębiorców, obawiających się utraty kontroli nad swoją działalnością gospodarczą (Mroczkowski 2006).

Decydujące dla rozwoju sektora biotechnologicznego interakcje pomiędzy uniwersytetami, przedsiębiorcami a lokalną i krajową władzą opisuje model „,potrójnej helisy” (Etzkowitz 1997, Lawton-Smith 2010). Według tej koncepcji, silne związki pomiędzy trzema uczestnikami modelu wraz z towarzyszącą im wymianą wiedzy tworzą korzystne warunki dla wzrostu i innowacyjności sektora.

Biorąc pod uwagę wskazane cechy charakterystyczne sektora biotechnologicznego a zwłaszcza wysokie ryzyko prowadzonej działalności, dominację małych i średnich przedsiębiorstw oraz długi czas prac $\mathrm{B}+\mathrm{R}$ - można by uznać wpływ biotechnologii na lokalny system społeczno-gospodarczy za minimalny. Nie należy jednak zapominać o takich właściwościach sektora, jak potencjał szybkiego wzrostu w przypadku sukcesu danego przedsięwzięcia oraz związanych z tym procesów naśladownictwa. Silna tendencja branży do koncentracji przestrzennej również ułatwia powstawanie i wzrost skupień w regionach sukcesu. Najważniejsza cecha sektora - wysoka innowacyjność - również wpływa na lokalną gospodarkę, kreując dobrze płatne miejsca pracy, zwiększając konkurencyjność i generując wysokie nakłady na prace B + R. Silne powiązania biotechnologii z innymi sektorami wysokich technologii, a zwłaszcza nanotechnologią, ICT (bioinformatyka), inżynierią materiałową i ochroną środowiska pozwalają traktować rozwój tej dziedziny jako fundament innowacyjności i konkurencyjności całej gospodarki regionu (Gertler 2009).

\section{BIOTECHNOLOGICZNE SPÓ£KI SPIN-OFF UNIWERSYTETU JAGIELLOŃSKIEGO}

Branża biotechnologiczna nie występuje jako wyodrębniony rodzaj działalności w klasyfikacjach działalności gospodarczej, nie istnieją również żadne kompletne zestawienia tego typu podmiotów. Stąd też identyfikacja tego typu spółek najczęściej jest zajęciem wymagającym opracowywania zestawień danych pochodzących z różnych źródeł.

Identyfikację krakowskich, akademickich spółek spin-off w sektorze biotechnologicznym rozpoczęto od kwerendy członków Klastra Life Science - lokalnej inicjatywy klastrowej, zrzeszającej przedsiębiorców z branży biotechnologicznej, farmaceutycznej i kosmetycznej. We wstępnie zidentyfikowanych spin-offach przeprowadzono serię wywiadów półustrukturyzowanych, zbierając informacje na temat pochodzenia firm, motywacji 
naukowców rozpoczynających własną działalność gospodarczą oraz najważniejszych zalet i trudności związanych z prowadzeniem firmy.

Ostatecznie na terenie Krakowa zidentyfikowano pięć biotechnologicznych spółek spin -off, wszystkie założone przez naukowców Uniwersytetu Jagiellońskiego (tab. 1). W trzech spośród nich udało się przeprowadzić wywiady z kadrą zarządzającą. Oprócz tego przeprowadzono wywiady w instytucjach otoczenia biznesu - Klastrze Life Science, Jagiellońskim Centrum Innowacji oraz funduszu kapitałowym JCI Venture.

Akademickie firmy spin-off UJ są działalnościami stosunkowo młodymi - najstarsza ze zidentyfikowanych firm powstała w 2004 roku. Wszystkie z badanych firm zaliczają się również do segmentu małych przedsiębiorstw (łączne zatrudnienie we wszystkich działalnościach wynosi 33 osoby). Zdecydowana większość specjalizuje się w rozmaitych zagadnieniach z zakresu biotechnologii medycznej.

Tab. 1. Biotechnologiczne firmy spin-off UJ

\begin{tabular}{|l|c|c|l|}
\hline & Rok powstania & $\begin{array}{c}\text { Liczba } \\
\text { zatrudnionych }\end{array}$ & \multicolumn{1}{|c|}{ Branża } \\
\hline BioCentrum & 2004 & 18 & medycyna \\
\hline BioTe21 & 2006 & 8 & medycyna \\
\hline Biospekt & 2008 & 1 & ochrona środowiska \\
\hline ScholaGene & 2008 & 1 & konsulting \\
\hline Hependo & 2010 & 5 & medycyna \\
\hline
\end{tabular}

Źródło: opracowanie własne

Badane spin-offy charakteryzują się rozmaitymi modelami biznesowymi prowadzonej działalności. Jedynie dwie z firm (BioCentrum oraz Hependo) prowadzą własne prace $\mathrm{B}+\mathrm{R}$, zgodne z omawianym wcześniej modelem komercjalizacji wiedzy w biotechnologii medycznej. Kolejne dwie firmy (BioTe21 i Biospekt) zajmują się sprzedażą produktów i usług na podstawie technologii i wiedzy pozyskanych przez założycieli w czasie swojej działalności naukowej (BioTe21 - diagnostyka genetyczna, Biospekt - szczepy bakterii używane w oczyszczalniach ścieków). Firmy te nie prowadzą własnych prac B+R. Wreszcie jedna firma (ScholaGene) specjalizuje się w świadczeniu usług doradczych dla firm i zespołów naukowych z dziedziny biotechnologii i nauk o życiu.

Spółki Hependo i BioCentrum, prowadzące prace B+R z zakresu innowacyjnych farmaceutyków, stanowią modelowe przykłady funkcjonowania dedykowanych firm biotechnologicznych, wraz z charakterystycznymi dla tej dziedziny: długim czasem prac badawczych, niepewnością rezultatów oraz koniecznością pozyskiwania zewnętrznego kapitału do czasu sprzedaży licencji/patentu. W przypadku firmy Hependo źródłem kapitału jest fundusz venture capital JCI Venture, co stanowi jeden z niewielu przykładów inwestycji tego typu instytucji w polskim sektorze biotechnologicznym. BioCentrum jest zaś spółką zależną od giełdowej grupy Selvita, która rozwinęła się po nawiązaniu kontaktów pomiędzy zespołem założycielskim BioCentrum z profesorem Adamem Dubinem na czele, a Pawłem 
Przewięźlikowskim, byłym wiceprezesem spółek Comarch i Interia, posiadającym długoletnie doświadczenie biznesowe. Od 2007 r. obie spółki funkcjonowały równolegle, posiadając jednak wspólny zarząd, adres i część pracowników, natomiast od 2008 r. właścicielem 100\% udziałów BioCentrum jest grupa Selvita. Grupa debiutowała na warszawskim alternatywnym rynku giełdowym NewConnect w 2011 roku, pozyskując dodatkowe fundusze na prowadzone prace $\mathrm{B}+\mathrm{R}$. Jak wspomniano wcześniej, jest także pierwszą polską spółką biotechnologiczną posiadającą umowę na komercjalizację swoich innowacji przez dużą korporację farmaceutyczną (Orion Pharma).

Wszystkie z badanych firm zlokalizowane są na terenie obiektów należących do Uniwersytetu Jagiellońskiego, bądź spółki-córki Uniwersytetu - Jagiellońskiego Centrum Innowacji. Przedsiębiorcy podkreślają, iż utrzymywanie aktywnych kontaktów z UJ jest również jedną z podstaw funkcjonowania opisywanych firm. Oprócz wynajmu powierzchni laboratoryjnej, Uniwersytet i jego pracownicy pozostają głównym źródłem innowacji i specjalistycznej wiedzy ukrytej dla przedsiębiorców. Kontakty i relacje nawiązane w czasie pracy naukowej często są podstawą poszukiwania potencjalnych klientów i kooperantów.

\section{NAJWAŻNIEJSZE BARIERY I CZYNNIKI WZROSTU}

Najważniejszą barierą w rozwoju własnej działalności, wskazywaną przez badanych przedsiębiorców jest utrudniony dostęp do kapitału finansowego. Szacują oni wartość kapitału początkowego, koniecznego do założenia firmy i przetrwania początkowego okresu działalności na ok. $20 \mathrm{mln}$ zł. Istotnym ograniczeniem jest też opłacalność zatrudniania etatowych pracowników, która pojawia się po przekroczeniu progu 500 tys. zł rocznego obrotu. Możliwość tworzenia nowych miejsc pracy przyspiesza rozwój przedsiębiorstwa, pozwalając na zintensyfikowanie prowadzonej działalności.

Barierą w rozwoju akademickich spin-offów jest także traktowanie przez właścicieli swoich działalności wyłącznie w kategoriach źródeł dodatkowego zarobku, przy zachowaniu etatów naukowych bądź dydaktycznych w instytucji-matce. Przedsiębiorcy tacy nie są w większości zainteresowani osiąganiem dominacji na rynku, wprowadzaniem nowych produktów i agresywnym rozwojem swoich spółek - najczęściej satysfakcjonuje ich osiąganie przez ich firmy pewnego stałego poziomu zysków. W przypadku osiągnięcia zakładanych przez założycieli zysków działalności takie w dużej mierze stagnują. W przypadku krakowskich firm spin-off przykładami takich działalności są firmy Biospekt i Scholagene. Powyższe zjawisko jest często spotykane wśród biotechnologicznych firm spin-off w Europie Środkowej i Wschodniej, m.in. w Estonii i na Węgrzech (Kukk 2008). Clarysse (2003), klasyfikując działalności sektora wysokich technologii ze względu na zamiary ich właścicieli, zalicza tego typu firmy do life style businesses. Pozostałe kategorie, wyróżnione przez tego autora to: gold-seeking businesses (agresywne, nastawione na podbój rynku i poszukiwanie dodatkowego finansowania działalności) oraz venture businesses (spółki wsparte przez fundusze kapitału zalążkowego).

Zainteresowanie władz Uniwersytetu tematyką transferu technologii i komercjalizacji wiedzy sięga początku lat 2000., kiedy to powołano do życia Centrum Innowacji, Transferu Technologii i Rozwoju Uniwersytetu (CITTRU) oraz uniwersytecką spółkę Jagiellońskie 
Centrum Innowacji (JCI). W 2007 r. na zlecenie tych instytucji wykonano Raport nt. komercjalizacji wyników badań naukowych $w$ dziedzinie life science $w$ Małopolsce, w ramach którego m.in. przeprowadzono wśród naukowców UJ serię wywiadów i ankiet, dotyczących zagadnień komercjalizacji. Najważniejszym wnioskiem płynącym z raportu była niewielka skala transferu technologii - jedynie 10\% ankietowanych naukowców zadeklarowało podejmowanie jakichkolwiek prób komercjalizacji wyników swoich badań (również poprzez sprzedaż licencji innym podmiotom gospodarczym). Za najważniejsze bariery w komercjalizacji uznano m.in. ograniczenia finansowe, brak osób i instytucji wspierających, trudności prawne i biurokratyczne, obciążenie obowiązkami na uczelni oraz brak biznesowego uzasadnienia komercjalizacji wyników prowadzonych badań. Problemem jest również np. nieuznawanie przez władze uczelni patentów jako dorobku naukowego. Jednocześnie prawie $80 \%$ ankietowanych zadeklarowało chęć skorzystania z usług uczelnianej jednostki, powołanej do wspierania transferu technologii i komercjalizacji.

Kamieniem milowym w rozwoju systemu wspierania komercjalizacji było oddanie w 2008 r. zarządzanego przez JCI budynku Parku Life Science - pierwszego w Polsce parku naukowo-technologicznego dedykowanego działalnościom z dziedziny biotechnologii i nauk o życiu. Wraz z działającym od 2006 r. Klastrem Life Science - inicjatywą klastrową, zrzeszającą krakowskie instytucje i firmy z branży nauk o życiu (w 2011 r. 64 członków, zatrudniających prawie 37000 ludzi), instytucje te stanowią podstawy budowanego systemu. Obecnie głównymi najemcami ponad $5000 \mathrm{~m}^{2}$ powierzchni Parku są firmy z sektora biotechnologicznego - m.in. Selvita, BioCentrum, Hependo oraz szerszego sektora nauk o życiu: Wessling, Miraculum oraz JCET. Park oferuje firmom wynajem powierzchni pod laboratoria i zaplecze biurowe, wyposażonej w podstawowe media i instalacje, jednakże pozbawionej sprzętu laboratoryjnego. Na 2012 rok planowane jest otwarcie kolejnych 2 budynków o powierzchni ok. $5000 \mathrm{~m}^{2}$ każdy, w tym również inkubatora technologicznego, oferującego wynajem wyposażonych powierzchni laboratoryjnych firmom w inicjalnej fazie rozwoju głównie spin-offom akademickim. Biorąc pod uwagę niedostatek powierzchni laboratoryjnych (lub możliwych do zaadaptowania na taką działalność) na rynku nieruchomości, dostęp do przygotowanej infrastruktury może mieć duże znaczenie dla przyszłego rozwoju sektora.

Elementem działalności JCI jest również organizacja działań Klastra Life Science, którego głównym zadaniem jest integracja środowiska przedsiębiorców, nauki i instytucji oraz wspieranie przepływów wiedzy (,,infrastruktura przepływów wiedzy”) pomiędzy członkami. Klaster organizuje m.in. spotkania, wykłady i kursy dla przedsiębiorców, koordynuje działania marketingowe i promocyjne (m.in. wspólne stoiska na targach branżowych, międzynarodowa kampania promocyjna „Bioregion Małopolska”), funkcjonuje także jako pośrednik w kontaktach z sieciami aniołów biznesu.

Słaba dostępność kapitału dla rozpoczynających działalność firm typu spin-off była wskazywana jako jedna z głównych barier komercjalizacji w polskiej branży biotechnologicznej. W krajach zachodniej Europy podstawowym źródłem finansowania tego typu działalności są fundusze kapitału zalążkowego (seed i venture capital), często dedykowane sektorowi nauk o życiu, ze względu na konieczność specjalistycznej analizy i oceny potencjału rynkowego danej innowacji. Istniejące w Polsce fundusze tego typu zwykle koncentrują się na branży ICT, bądź też na działalnościach mniej zaawansowanych technologicznie. Powołany w 2008 r. fundusz JCI Ventrue, wspólne przedsięwzięcie JCI i funduszu zalążkowego Satus, jest pierwszym polskim funduszem kapitału zalążkowego specjalizującym się we wspieraniu 
wysokoinnowacyjnych działalności z sektora biotechnologicznego i nauk o życiu. Obecnie (2011 r.) fundusz posiada udziały w 4 spółkach spin-off, z czego 3 specjalizują się w pracach $\mathrm{B}+\mathrm{R}$ z dziedziny biotechnologii medycznej. Zarząd funduszu planuje powoływanie kilku spółek każdego roku, za swoją największą przewagę nad innymi tego typu działalnościami w Polsce uznając dostęp do wysokowykwalifikowanych brokerów technologii (biotechnologów, farmaceutów, chemików, lekarzy), oceniających analizowane projekty pod względem rzeczywistego potencjału rynkowego, który często jest nieumiejętnie prezentowany przez stawiających pierwsze kroki w biznesie naukowców.

\section{PodsumowANIE I WNIOSKI}

Działalność akademickich firm spin-off, zakładanych przez naukowców UJ, posiada wiele cech uznawanych za charakterystyczne dla tego typu podmiotów. Najważniejszą z nich jest tendencja do przestrzennej koncentracji i tworzenia skupień, silnie związanych z lokalnym środowiskiem. Akademickie firmy biotechnologiczne utrzymują silne związki z Uniwersytetem, który jest dla nich nie tylko źródłem wiedzy i innowacji, na których opierają swoją działalność, ale także dostawcą powierzchni laboratoryjnych oraz - poprzez sieci nieformalnych kontaktów - źródłem wiedzy na temat potencjalnych klientów, dostawców czy kooperantów.

Typowy dla tego rodzaju działalności jest również niedostatek kapitału i próby alternatywnego finansowania prowadzonych prac B+R przez badania usługowe i debiut giełdowy (Selvita-BioCentrum), bądź też zaangażowanie funduszy kapitału zalążkowego (Hependo).

Wpływ na rozwój firm posiada także model prowadzonej działalności. Stosując opisaną wcześniej klasyfikację Clarysse'a (2003), dwie z badanych firm (Biospekt, Scholagene) można zaliczyć do lifestyle business, jedną (Hependo) do venture business, zaś dwie (BioCentrum, BioTe21) do kategorii gold seekers.

Działalność firmy BioCentrum, wraz z późniejszym połączeniem ze spółką Selvita oraz dynamicznym wzrostem można uznać za lokalną historię sukcesu, która może mieć wpływ na późniejsze procesy naśladownictwa. Historia tej firmy ukazuje jednocześnie problemy, z jakimi borykają się rozpoczynający działalność gospodarczą naukowcy (brak kapitału) oraz perspektywy rysujące się przed wysokoinnowacyjnymi działalnościami w przypadku doinwestowania i odpowiedniej polityki finansowej zarządu (debiut giełdowy, badania usługowe, wreszcie - umowa komercjalizacyjna z korporacją Orion).

Kraków jest pierwszym miastem w Polsce, w którym rozpoczęła się budowa systemu wsparcia komercjalizacji innowacji w dziedzinie nauk o życiu. Działalność Jagiellońskiego Centrum Innowacji wraz z Parkiem Life Science i Klastrem stanowi przystosowaną do polskich warunków adaptację wzorców z największych skupień biotechnologicznych Europy zachodniej, np. Oxfordu wraz z będącą własnością tamtejszego uniwersytetu spółką Isis Innovation (Lawton-Smith 2004). Przedstawiciele zarządu JCI i Klastra uznają wspieranie akademickich działalności spin-off za fundament rozwoju krakowskiego skupienia firm z sektora nauk o życiu, stąd też koncentracja na wsparciu dla małych przedsiębiorstw, znajdujących się w inicjalnej fazie rozwoju. Pogląd ten jest zgodny z wynikami empirycznych badań przeprowadzanych $\mathrm{w}$ rozwiniętych skupieniach Europy zachodniej oraz Ameryki Północnej (m.in. Coenen 2004, Gertler 2009, Lawton-Smith 2006, 2008), ukazujących sek- 
tor biotechnologiczny jako silnie zglobalizowany (pod względem przepływów wiedzy i rozprzestrzeniania się innowacji) i jednocześnie mocno związany z lokalnym środowiskiem społeczno-gospodarczym, które jest źródłem wzrostu branży.

Model ,ppotrójnej helisy” Etzkowitza, opisującej interakcje otoczenia innowacyjnego biznesu korzystne dla jego wzrostu, w przypadku krakowskim jest jedynie częściowo rozwinięty. Relacje pomiędzy nauką i biznesem, pomimo zmian mających miejsce w ostatnich latach (powołanie CITTRU, JCI i Klastra, którego UJ jest członkiem-założycielem) wciąż pozostawiają wiele do życzenia, o czym świadczą wyniki badań przedstawione w Raporcie nt. komercjalizacji (2007). Również zaangażowanie ze strony władz lokalnych, regionalnych i centralnych jest minimalne. Funkcjonujący od 2007 roku przy Ministerstwie Nauki i Szkolnictwa Wyższego Interdyscyplinarny Zespół ds. Rozwoju Biogospodarki, kierowany przez prof. A. Dubina (założyciela BioCentrum) został rozwiązany po opublikowaniu jednego raportu ze swojej działalności (Stan i kierunki rozwoju biogospodarki, MNiSW 2007). Na szczeblu wojewódzkim i miejskim, pomimo formalnego uczestnictwa ww. urzędów w Klastrze Life Science, próżno szukać jakichkolwiek odniesień do rozwoju sektora nauk o życiu w dokumentach, strategiach i planach rozwoju.

Powyższa sytuacja stawia jednostki szkolnictwa wyższego na pozycji jedynych instytucji zainteresowanych realnym wsparciem rozwoju sektora biotechnologicznego i akademickiej przedsiębiorczości. Działalność JCI jest przykładem systemowego podejścia do tego zagadnienia, jednakże efekty obecnych działań będą rozpoznawalne dopiero w długofalowej perspektywie - doświadczenia z badań nad rozwiniętymi skupieniami biotechnologicznymi pokazują, iż okres od rozpoczęcia działań promujących komercjalizację przez tworzenie akademickich spółek spin-off wraz z systemem wsparcia do odnotowania realnego wzrostu liczby i rentowności przedsiębiorstw wynosi średnio ok. 10 lat (Lawton-Smith 2006). W przypadku Krakowa przełomowym dla akademickiej przedsiębiorczości biotechnologicznej wydarzeniem może być rozpoczęcie działalności przez Inkubator Life Science w 2012 roku. Jako że usługa taka nie była dostępna nigdy wcześniej w Polsce, jej działalność może przyczynić się do znacznego wzrostu liczby akademickich firm spin-off. Zagadnienie to, podobnie jak całość tematyki akademickiej przedsiębiorczości w sektorach wysokich technologii, z pewnością wymagać będzie dalszych badań w przyszłości.

\section{Literatura}

Abramovsky L., Simpson H., 2011, Geographic proximity and firm-university innovation linkages: evidence from Great Britain, "Journal of Economic Geography", 11/2011, Oxford University Press, s. 949-977.

Andersson T., Gleadle P., Haslam C., Tsitsianis N., 2010, Bio-pharma: a financialized business model, "Critical Perspectives on Accounting", 21, Elsevier, s. 631-641.

Birley S., 2002, Universities, Academics and Spinout Companies: Lessons from Imperial, International "Journal of Entrepreneurship Education", 1/1, s. 133-153.

Boschma R.A., Wentig R., 2004, The spatial evolution of British automobile industry, "Papers in Evolutionary Economic Geography”, 05/04, Utrecht University, Utrecht.

Clarysse B., Degroof J., Heirman A., 2003, Growth paths of technology-based companies in life sciences and information technology, Office for Official Publications of the European Communities, Luxembourg. 
Coenen L., Moodysson J., Asheim B.T., 2004, Nodes, Networks and Proximities: On the Knowledge Dynamics of the Medicon Valley Biotech Cluster, "European Planning Studies", vol. 12, No 7, Carfax Publishing, s. 1003-1018.

Cooke P., 2004, The accelerating evolution of biotech clusters, "European Planning Studies”, vol. 12, No 7, Carfax Publishing, s. 915-920.

Decarolis D.M., Deeds D.L., 1999, The Impact of Stocks and Flows of Organizational Knowledge on Firm Performance: An Empirical Investigation of the Biotechnology Industry, "Strategic Management Journal", 20/10, Wiley-Blackwell, s. 953-968.

Eliasson G., 2000, Industrial policy, competence blocs and the role of science in economic development, "Journal of Evolutionary Economics", vol. 10, Springer Verlag, s. 217-241.

Etzkowitz H., Leydesdorff L., 1997, Universities and the global knowledge economy, Pinter, London.

Gertler M., Vinodrai T., 2009, Life Sciences and Regional Innovation: One Path or Many?, "European Planning Studies", vol. 17, No 2, Routledge, London, s. 235-260.

Kukk P., Truve E., 2008, Estonian Biotechnology Strategy 2008-2013, Estonian Biotechnology Association, Tallin.

Landry R., Amara N., Rherrad I., 2006, Why are some university researchers more likely to create spin-offs than others? Evidence from Canadian universities, "Research Policy", 35, Elsevier, s. 15991615.

Lawton-Smith H., 2004, The Biotechnology Industry in Oxfordshire: Enterprise and Innovation, "European Planning Studies", vol. 12, No 7, Carfax Publishing, s. 985-1001.

Lawton-Smith H., Ho K., 2006, Measuring the performance of Oxford University, Oxford Brookes University and the government laboratories' spin-off companies, "Research Policy", 35, Elsevier, s. $1554-1568$.

Lawton-Smith H., Romero S., Bagchi-Sen S., 2008, Oxfordshire biomedical university spin-offs: an evolving system, "Cambridge Journal of Regions, Economy and Society", 1/2008, s. 303-319.

Lawton-Smith H., Bagchi-Sen S., 2010, Triple helix and regional development: a perspective from the Oxfordshire in the UK, "Technology Analysis \& Strategic Development", 22/7, Routledge, London, s. 805-818.

Mroczkowski T., Khilji S.E., Bernstein B., 2006, From invention to innovation: toward developing an integrated innovation model for biotech firms, "Journal of Product Innovation Management", 23, Product Development \& Management Association, s. 528-540.

Nicolaou N., Birley S., 2003, Academic Networks in trichotomous categorization of university spin-outs, "Journal of Business Venturing", 18, s. 333-359.

Porter M.E., 1990, The Competitive Advantage of Nations, Free Press, New York.

Regulamin: Zasady tworzenia spótek spin-off w Uniwersytecie Jagiellońskim.

Raport nt. komercjalizacji wyników badań naukowych w dziedzinie life science w Małopolsce, 2007, Jagiellońskie Centrum Innowacji, Kraków.

Sorenson O., 2003, Social networks and industrial geography, "Journal of Evolutionary Economics", 13, Springer Verlag, s. 513-527.

Tamowicz P., 2006, Przedsiębiorczość akademicka: spótki spin-off w Polsce, Polska Agencja Rozwoju Przedsiębiorczości, Warszawa.

Ter Wal A.L.J., Boschma R.A., 2007, Co-evolution of firms, industries and networks in space, "Papers in Evolutionary Economic Geography”, 07/07, Utrecht University, Utrecht. 


\section{Jagiellonian University's spin-off biotechnological companies as a mechanism of technology transfer}

Spin-off companies constitute an interesting subject of research for economic geographers. The significance of local knowledge networks, tacit knowledge flows and strong links with local social and economic environment are their most important features. Academic spin-offs, created by employees of higher education and R\&D establishments, form a specific subgroup among these firms. Spin-off companies are acknowledged as a most important technology transfer mechanism in the highly innovative modern biotechnology sector.

This paper deals with the creation and functioning of the Jagiellonian University's biotech spin-off companies in the contemporary business environment of Poland. Most of these companies are in an initial phase of development, facing many problems with financing and bureaucracy. The most important barriers to popularization of spin-off activity among researchers are: lack of financing, complicated IP law system, lack of business knowledge among scientists and general focus only on scientific activity among research personnel. The role of Jagiellonian University's technology transfer and entrepreneurship support agencies (i.e. the Jagiellonian Centre of Innovation and the Life Science Technology Park and Cluster) is also discussed.

Mgr Piotr Dawidko

Uniwersytet Jagielloński, Kraków

Instytut Geografii i Gospodarki Przestrzennej

Zakład Rozwoju Regionalnego

e-mail: piotr.dawidko@uj.edu.pl 